\title{
50 YEARS OF THE PRAGUE SPRING: A MEASURE OF THE IMPACT OF HISTORY ON CONTEMPORARY RELATIONS BETWEEN RUSSIA, THE CZECH REPUBLIC AND SLOVAKIA
}

\begin{abstract}
The $50^{\text {th }}$ anniversary of the Prague Spring is marked in 2018. Today, the events of 1968 retain their significance for relations between Russia, the Czech Republic and Slovakia. The subject of the research is the impact of the events of the Prague Spring in 1968 on current relations between Russia and the countries of the former Czechoslovakia. The author analyzes in detail the key causes and consequences of the Prague Spring, as well as the current state of Russian-Czech and Russian-Slovak relations in conditions of anti-Russian sanctions.

Analyzing the role of the attitudes of modern Czechs and Slovaks to the events of 1968, the author concluded that for the citizens of the Czech Republic and Slovakia, they are more historical. Condemning the entry of Warsaw Pact troops into Prague, Russia closed this chapter in its relations with the countries of the former Czechoslovakia. At the same time, the Czech Republic and Slovakia, becoming separate countries, overcame the problems in their relations in the $20^{\text {th }}$ century.

The article demonstrates that the deterioration of bilateral relations between Russia and the Czech Republic and Russia and Slovakia is due not to unsatisfied historical claims, but to the general cooling in relations between Russia and the EU and the policy of sanctions. Today, Prague and Bratislava are forced to
\end{abstract}


balance between Brussels and Moscow, seeking to ensure their national interests, which for the Czech Republic and Slovakia are inextricably linked with both the European Union and Russia.

The novelty of the research lies in the study of relations between Russia, the Czech Republic and Slovakia through the prism of the evolution of their cultural and historical determinants. Thus, the author used the case study method and content analysis in his research. The theoretical basis of the research was the works of both Russian and foreign authors. The practical basis of the study was data from sociological surveys conducted in the Czech Republic and Slovakia in recent decades, as well as the evidence of eyewitnesses of the events of the Prague Spring.

\section{Key words}

Russia, Czech Republic, Slovakia, the Prague Spring, sanctions

Last year was the fiftieth anniversary of Prague Spring. Today, the events of 1968 remain essential for relations between Russia, the Czech Republic, and Slovakia. On 5 January 1968, Alexander Dubcek, a politician whose goal was to liberalize the country and bring it closer to the West, was elected First Secretary of the Communist Party of Czechoslovakia. Thus began the Prague Spring, which became a landmark episode not only in the history of Czechoslovakia but throughout Eastern Europe. The program of reforms proposed by Dubcek was called "Socialism with a human face".

As noted by Czech historian Jan Adamek (2004, p. 112), this slogan was "an example of excellent political marketing, the vague phrase allowed the widest interpretation, from the 'humane' Communist dictatorship to liberal democracy with socialist elements". Dubcek launched reforms, the key of which was the abolition of censorship in April 1968.

Society met Dubcek's transformation with great enthusiasm. Although the first Secretary of Czechoslovakia did not intend to break with Moscow and deprive the Communists of power, the mood in society was anti-Soviet. Such a "turn to the West" in Czechoslovakia could not but cause concern among the political leadership of the USSR, which initially sought to influence the Prague events by peaceful means.

It is important to note that the leaders of the GDR and Poland, who feared the spread of liberal ideas in their countries, expressed great concern at that time. Thus, at the meeting of the Communist parties in Dresden on 23 March 
1968, the Polish leader, Wladyslaw Gomulka, and the First Secretary of the Central Committee of the Socialist United party of Germany, Walter Ulbricht, announced a creeping counter-revolution in Czechoslovakia. In many ways, the GDR and Poland were supporters of resolving the crisis by force.

By the summer of 1968, the situation was heating up. The press in Czechoslovakia, taking advantage of the declared freedom of speech, was sharp in its criticism of the USSR. Dissidents such as Milan Kundera and Vaclav Havel, sensing the support of the West, called for anti-state action. The dialogue between Moscow and Prague, initiated in meetings in Cierna nad Tisou and Bratislava, had stalled. It became apparent that Dubcek was no longer able to control the growing wave of anti-Soviet sentiment in Czechoslovakia.

On $21^{\text {st }}$ August 1968 troops of the Warsaw Pact entered Czechoslovakia and anti-Soviet protests were suppressed by force. These events completely changed foreign and domestic policy in Prague, all reforms were canceled, and Dubcek himself was removed from the post of first Secretary of the Central Committee of the HRC. In December 1970, the document "Lessons of crisis development in the party and society following the XIII Congress of the HRC" was adopted, condemning Dubcek's political course.

By the end of the 1980s, the events of the Prague Spring had been rethought. In a statement of the Soviet government of 5 December 1989, "the decision to bring allied forces into Czechoslovakia was found to be erroneous as unjustified interference in the internal affairs of a sovereign state" (Rossija..., 2002, p. 341).

After the "Velvet Revolution," Dubcek returned to politics becoming the Chairman of the new Parliament at the end of 1989. On 26 February 1990, an agreement was signed on the complete withdrawal of Soviet troops from Czechoslovakia.

Today Dubcek's actions during the Prague Spring, especially his line in relations with Moscow, are sharply criticized by Czech politicians. Thus, the current President of the Czech Republic Milos Zeman (2018) said that "Dubcek could not protect the country, and his policy of concessions to the occupiers and agreement led the country into moral insanity, which lasted until the end of the Communist regime". Dubcek is also accused of allegedly knowing about the impending military operation but not taking any action.

The events of the Prague Spring, on the one hand, revealed the crisis of socialist construction in the USSR, and on the other - caused a wide public outcry and split the socialist camp. As accurately observed Russian researcher Musatov (2010, p. 46), "the end of the Prague Spring once again reminded the socialist countries of their limited sovereignty and the inability to go beyond the Soviet 
bloc". Be that as it may, it was the events of the Prague Spring that became the leitmotif of the Velvet Revolution of 1989, and one of the key arguments in favor of the entry of the Czech Republic and Slovakia into Euro-Atlantic structures.

The results of studies of the attitudes of modern Czechs and Slovaks to the events of 1968 say that the age of the respondents plays a vital role here. Witnesses of the Prague Spring have a negative attitude to the actions of the USSR, while for the younger generation it represents closed chapters of history. Since the Soviet troops left after the Velvet Revolution, for most of society, the topic is exhausted and finished.

Russians are treated better by the Slovaks than their neighbors, according to opinion polls (2018), and the events of the Prague Spring "are perceived in the context of the cold war and the policy of the Brezhnev leadership of the Soviet Union, and not as the will of the Russian people".

It should be noted that when in 2007 Prague was invited to join the missile DEFENSE system in Europe, about 70\% of Czechs opposed the placement of a radar on their territory, primarily because of their reluctance to worsen their relations with Russia.

However, sometimes, the events of the past and forgotten grievances still make themselves felt. So, in 2015, a great dissatisfaction among the Czechs and Slovaks was caused by a documentary about the fateful days of August 1968, which was broadcast by the TV channel Russia 1. As stated in the official statement from Bratislava, "the invasion of Soviet troops is presented as a friendly step to protect the country from a potential threat". The Slovak Foreign Ministry (2018) stressed that they insisted on "respecting the truth", especially in the context of "a great tragedy for Czechoslovakia and its citizens".

In November 2017, during the official visit of Czech President Zeman to Moscow, the Russian TV channel Zvezda posted on its website "Czechoslovakia should be grateful to the USSR for 1968", which caused a storm of indignation in the Czech Republic. In response to the request by Zeman to condemn the actions of the newspaper, the Prime Minister of Russia Dmitry Medvedev (2018) stated that "Russia enshrines the principle of non-interference in the activities of the media", and stressed that "this publication does not represent the official position of the country".

In general, it can be argued today that what exerts the negative impact on Russia's relations with the Czech Republic and Slovakia is not their historical past, but the general tension between Russia and the West.

It is impossible not to mention such an essential problem in the history of Czechoslovakia as the relationship between the Czechs and the Slovaks, which 
has always been ambiguous. The Czechoslovak Republic was established in 1918; however, this decision was dictated more by political necessity than by the desire of their peoples. Tensions between the Czechs and the Slovaks arose as early as the 1920s when Slovak politicians began to seek autonomy, which they claimed was promised to Slovakia when the Republic was established.

After the end of the Second World War, the Czechs and Slovaks were again not united in their views on the future of the state system. In the Czech lands, in the elections of 1946, the Communist party won, and in the Slovak - the Democratic party who did not want to give a monopoly of power to the Communists. However, thanks to the support of Moscow, the ruling party in Czechoslovakia was the $\mathrm{CP}$, in which the Czechs held most of the critical positions. Interestingly, the ideologist of the Prague Spring Dubcek was the first Slovak head of Czechoslovakia, which was unprecedented in a country where Slovaks were considered second-class people.

By the end of the 1980s, the concept of "Czechoslovakism", which claimed that "Czechoslovaks" are a single people, had utterly outlived its usefulness. "In 1990, 45\% of Czechs and Slovaks surveyed described relations between their peoples as indifferent or dysfunctional" (Stykalin, 2010, p. 17). In the 1992 elections, political forces came to power in Czechoslovakia, preferring the division of the country. Even though according to surveys in March 1992, only 17\% of Slovaks and $11 \%$ of Czechs supported the independence of the republics, no one spoke for the preservation of a single state, Czechoslovakia.

Modern Russian-Czech relations are regulated by the Treaty on friendly relations and cooperation between Russia and the Czech Republic, in which the actions of the Warsaw Pact countries during the Prague Spring are called an "unacceptable use of force against Czechoslovakia in 1968 and further unjustified stay of Soviet troops on Czechoslovak territory" (Dogovor..., 2005, p. 112).

Today, the position of the Czech Republic and Slovakia concerning Russia is becoming an increasingly important economic factor. In 2012, the Russian Sberbank bought the Eastern European division of the Austrian Volksbank, which included Czech financial transactions. At that time, many foreign analysts began to criticize this decision, noting that the expansion of the presence of Russian capital can lead to the increased influence of Moscow on the foreign policy of Prague.

A characteristic phenomenon in recent decades has been the massive influx of Russian tourists to the Czech Republic. Before the crisis in relations between Russia and the West, in cities such as Karlovy Vary, up to $60 \%$ of the profits of the tourism sector were accounted for by Russian tourists. Most of the elite 
real estate in Karlovy Vary was bought by visitors from Russia at prices above the market. However, the EU's sanctions policy has led to a significant outflow of Russian capital. Tourist numbers and, accordingly, revenue decreased by about $50 \%$, and in the resort area $70-80 \%$ of apartments are now empty as their own-

ers have returned home. This caused discontent among the Czech population, which in turn influenced its electoral behavior.

\section{REFERENCES}

Adamec, J. (2004). Between Socialist Friendship and National Indifference. Budapest: CEU.

Byl raschjot sprovocirovat' SSSR: pochemu «Prazhskaja vesna» zakonchilas' provalom. (2018, 15 Jan). RT. Retrieved from https://russian.rt.com/science/article/467315prazhskaya-vesna-50-let

Chehi i slovaki vozmusheny rossijskim fil'mom o 1968 gode. (2018). BBC. Russkaja sluzhba. Retrieved from http://shhshhshh.bbc.com/russian/international/2015/06/150601_ czechs_slovaks_russians_roshh_over_film

Chehi i Slovaki: neprostoj «brak» i tihij «razvod». (2018). Radio Praga. Russkaja Sluzhba. Retrieved from http://shhshhshh.radio.cz/ru/rubrika/progulki/chehi-i-slovaki-neprostoj-brak-i-tihij-razvod

Chekanova, A. (2013, 22 Aug). Zeman schitaet Dubcheka predatelem. Radio Praga. Russkaja Sluzhba. Retrieved from www.radio.cz/ru/rubrika/novosti/zeman-schitaet-dubcheka-predatelem--1

Dogovor o druzhestvennyh otnoshenijah i sotrudnichestve mezhdu Rossijskoj Federaciej $i$ Cheshskoj Respublikoj [Treaty on friendly relations and cooperation between Russia and the Czech Republic]. 1993, Aug 26. In Bjulleten' mezhdunarodnyh dogovorov 7 (2005).

Groszkowski, J., Iwański, T., \& Sadecki, A. (2017). A neighbour discovered anew. The Czech Republic, Slovakia and Hungary's relations with Ukraine. Ośrodek Studiów Wschodnich im. Marka Karpia Centre for Eastern Studies. Warsaw.

Medvedev i Zeman obsudili stat'ju v "Krasnoj zvezde” o sobytijah 1968 goda. (2017, 22 Nov). RIA Novosti. Retrieved from https://ria.ru/politics/20171122/1509355595.html Musatov, V. L. (2010). Rossiia v pautine globalizatsii. Moskva: Vostok-Zapad.

Názory na vztahy národov a národnosti ČSSR. - IVM: Závěrečná sprava z vyzkumu. Pr., 1990. Č. 89/6. pp. 17-25.

Prečo majú Slováci radi Rusov napriek propagande. Napalete. (2016, 13 Oct). Retrieved from https://www.napalete.sk/preco-maju-slovaci-radi-rusov-napriek-propagande/ Robert Fico považuje Rusko za spolahlivého partnera v oblasti energetiky. (2016, 25 Aug). Retrieved from http://strana-smer.sk/robert-fico-povazuje-rusko-za-spolahliveho-partnera-v-oblasti-energetiky 
Rossija (SSSR) v vojnah vtoroj poloviny XX veka. (2002). Moscow: Triada-farm.

Stykalin, A. S. (2010). Prazhskaja vesna: problemy izuchenija. razmyshlenija po itogam konferencii. // Slavjanovedenie, 3, pp. 44-61.

Tamkin, E. (2017, 13 Oct). Why Americans Should (Maybe) Worry About Czech Elections. Foreign Policy. Retrieved from http://foreignpolicy.com/2017/10/13/whyamericans-should-maybe-worry-about-czech-elections/

Truhachev, V. V. (2017, 4 Dec). Chehija: raskol iz-za antirossijskih sankcij. RSMD. Retrieved from http://russiancouncil.ru/analytics-and-comments/analytics/chekhiyaraskol-iz-za-antirossiyskikh-sanktsiy

Vybory prezidenta Chehii: udastsja li pobedit' Milosha Zemana? (2018, 11 Jan). Deutsche Welle. Retrieved from www.dw.com/ru/vybory-prezidenta-chehii-udastsja-li-pobedit'-milosha-zemana/a-42086106 